\title{
Japan's High-Technology Trade with China and Its Export Control
}

\author{
Tomoo Marukawa
}

While Japanese business interests support the export of high-technology items and the transfer of technology from Japan to China, these economically motivated actions may have direct and indirect impacts on Japan's national security. First, the transfer of dual-use technology to China may directly help China's military buildup. Second, high-tech exports and technology transfers may have an indirect effect by eroding Japan's technological advantages vis-à-vis China. In this article I place these concerns into a historical context and analyze the current challenges to Japan's export control policies. I offer an overview of the JapanChina trade relationship, with a special focus on high-tech trade. I then discuss changes in Japan's export controls regarding China, based on heightened security concerns. Evidence indicates that the Japanese government is ill equipped to deal with "technology leakage," which is accelerating the erosion of Japan's technological supremacy and is not covered by its current export control regime. KEYwORDs: export control, Japan, China, high technology, dual-use technology, technology transfer, technology leakage

WITH THE ECONOMIC AND MILITARY RISE OF CHINA AND THE TENSIONS with China caused by territorial disputes over the Senkaku/Diaoyu Islands, Japan faces a serious dilemma. Business interests support the export of high-technology items and the transfer of technology to China. For example, in 2009, China became Japan's largest export destination, taking over that position from the United States. Currently, more than half of Japan's exports to China consist of machinery, including highly sophisticated industrial machinery that supports China's manufacturing. In addition, nearly 23,000 subsidiaries of Japanese companies operated in China at the end of 2011. But such economically motivated actions may have direct and indirect impacts on Japan's national security. First, the transfer of dual-use technology 
to China may help China's military buildup. Second, high-tech exports and technology transfers may lead to the erosion of Japan's technological advantages vis-à-vis China.

Arguably, Japan's economic and technological supremacy have been the basis for a sound bilateral relationship between Japan and China. China sees Japan as an indispensable source of capital investment and advanced technology, which China needs as it modernizes. Although the Chinese were occasionally offended by Japan's treatment of historical issues, China has had good reason to maintain a sound relationship with Japan. With the wane of Japan's economic and technological supremacy, however, China's motivation to refrain from outright confrontation with Japan has diminished. It is not a coincidence that Sino-Japanese relations have deteriorated since 2010, the first year that China's GDP exceeded that of Japan.

These concerns have once again triggered debate on Japan's export control policies. Japan joined its Western allies in exercising restrictions on its exports to the Eastern bloc, including China, in the 1950s. After the end of the Cold War, Japan joined some international export control regimes that aim to prevent the proliferation of weapons of mass destruction, such as missiles and nuclear and chemical weapons. Japan's commitment to these export control regimes, however, was mainly driven by (1) a desire to maintain good economic relationships with its allies and (2) a national commitment to be a "peace-seeking nation" (heiwa kokka) rather than by its own security concerns. It is perceived, perhaps without serious examination, that Japan's exports and technology transfer to China have made little contribution to Chinese military modernization. What is of more concern in Japan are the ongoing "technology leakages" through formal and informal channels that undermine Japan's technological supremacy, but are out of the reach of the current export control regime. The present export controls seem to be ill-suited to cope with the challenges to Japan's national security caused by China's rise.

In this article I place the recent conflict between Japan's business interests and its security concerns into a historical context and analyze the current challenges to its export control policies. In the second section I offer an overview of the Japan-China trade relationship, with a special focus on high-tech trade. In the third section I deal with changes in Japan's export controls regarding China. Japan's concentration on economic development after World War II led it to turn a blind eye to security issues in shaping its trade policy. Export 
controls have been regarded by Japanese businesses as an obstacle to their pursuit of commercial interests in China. With a strong business interest and a basically amicable relationship with China during the 1980 s and 1990s, Japan often took the risk of attempting to export sensitive high-technology items, which were sometimes halted by Coordinating Committee for Multilateral Export Controls (COCOM) restrictions. A turning point was the "Toshiba Machinery Incident" in 1987, which ignited severe criticism from the United States. The Japanese government and industries took the lesson seriously and reinforced the export control regime.

In the fourth section I deal with technology leakage, a problem that is not covered by Japan's current export control regime and yet may have an indirect impact on Japan's national security through the erosion of its technological supremacy. Evidence indicates that the Japanese government is not well equipped to deal with this problem either. With the increasing sense of economic and military threat from China in Japan, the government may be forced to take effective measures to prevent leakages.

\section{Overview of Bilateral Trade}

Japan has been one of the most aggressive among Western nations in expanding trade and investment relations with China. After 1972, Japan quickly established itself as China's most important trading partner, accounting for more than 20 percent of China's total exports and imports during the 1970s and 1980s. China's rich supply of primary goods, especially of petroleum and coal, prompted Japan initially to establish good economic relations. Heavily dependent on petroleum imports from the Middle East and suffering from two oil crises during the 1970s, Japan needed alternative energy supplies. The Japanese government entered an eight-year trade agreement with China in 1978 to import Chinese petroleum and coal in exchange for exports of Japanese manufacturing equipment and building materials (Kojima 2012a).

China, on the other hand, saw Japan as an indispensable source of technology and capital that could promote the modernization of its industries, because the United States and Western Europe had more technology transfer restrictions than Japan, at least at the beginning of China's open-door policy. In 1978, for example, China signed contracts with Western companies to buy manufacturing equipment worth US\$6 billion, 64 percent of which were signed with Japanese 
486

Japan's High-Technology Trade with China

companies (Kojima 2012b). Japan was also the first among Western nations to provide official development assistance to China (Sekiyama 2012).

With the opening of coastal regions to foreign direct investment and the depreciation of the renminbi, China has emerged as a major exporter of labor-intensive goods since the latter half of the 1980s. Japan-China trade during late 1980s and 1990s could be characterized as "vertical inter-industry trade," an exchange of labor-intensive manufactured goods made in China for sophisticated industrial machinery and key components made in Japan. However, bilateral trade has gradually evolved into "intra-industry trade," as indicated by the rise of the intra-industry trade index (Grubel-Lloyd index) in Figure $1 .{ }^{1}$ This is because machinery has become the most important item in both Japan's exports and imports with China, accounting for 55 percent and 42 percent in 2011, respectively. Within the machincry industry, industrial machinery and automobiles mainly flow from Japan to China, while electronic goods, office machines, and computers mainly flow from China to Japan. According to an analysis by Fukao, Ishido, and Ito (2003), Japan-China trade can now be charac-

Figure 1 Intra-Industry Trade Index of Japan-China Trade

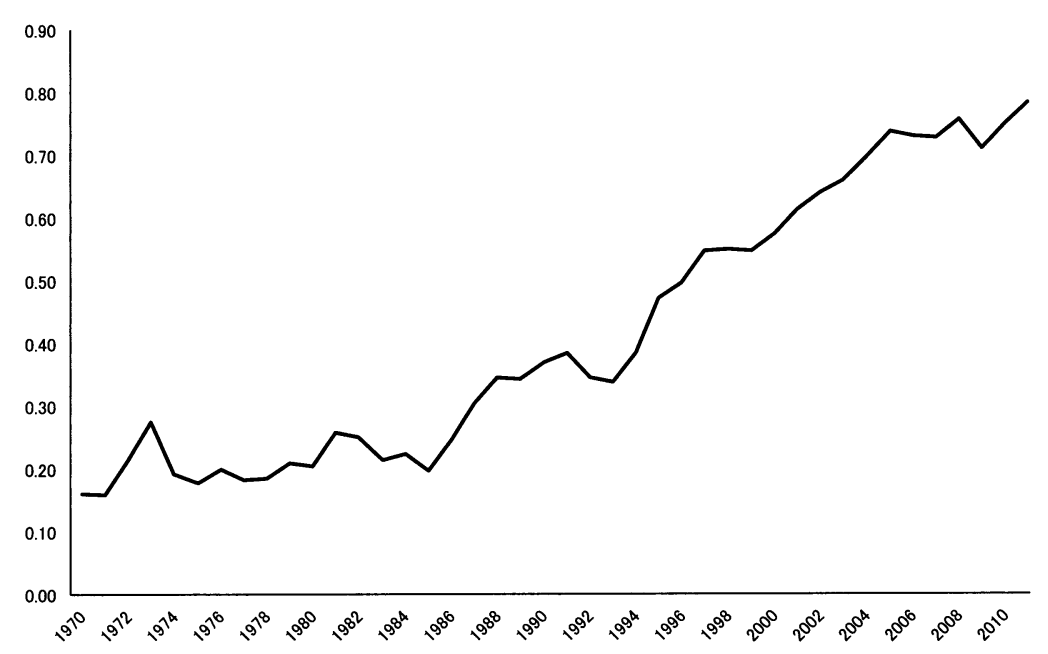

Source: Calculated by the author on the basis of Japanese customs statistics.

https://doi.org/10.1017/S1598240800008316 Published online by Cambridge University Press 
terized as "vertical intra-industry trade," in which Japan exports high-priced goods and China exports low-priced goods within the same industry.

The above analysis suggests that technology-intensive goods have been increasing in importance in Japan-China trade. Indeed, many items that Japan exports to China involve dual-use technologies. Exporters must get permission from the Ministry of Economy, Trade, and Industry (METI) to export them.

In Table 1, I have identified the classes in the Harmonized Commodity Description and Coding System that roughly correspond to the items on the list of sensitive merchandise and technology that Japan has committed to control through its membership in international export control regimes. I then gathered the classes into ten groups and calculated the share of each group in Japan's exports to China. I estimate that around 15 percent of Japan's exports to China are of sensitive items. Integrated circuits had the largest share among the items on the list. Other electrical machinery, which had the second-largest share in 2010, includes telecommunications equipment such as electronic switches and optical fibers, video recording apparatus, and primary cells. Other machinery, which represented 2 percent of Japan's exports to China in 2010, includes bearings, com-

Table 1 Shares of Sensitive Items in Japan's Exports to China (percentage)

\begin{tabular}{lrrrrrr}
\hline & 2005 & 2006 & 2007 & 2008 & 2009 & 2010 \\
\hline Integrated circuits & 5.6 & 6.5 & 7.4 & 6.5 & 6.7 & 6.2 \\
Other electrical machinery & 1.6 & 1.7 & 3.1 & 3.0 & 3.0 & 2.0 \\
Other machinery & 2.3 & 2.0 & 1.8 & 1.7 & 2.0 & 2.0 \\
Optical, measurement, & & & & & & \\
$\quad$ and analysis instruments & 2.2 & 1.9 & 1.9 & 1.8 & 1.8 & 1.7 \\
Machine tools & 1.4 & 1.5 & 1.3 & 1.2 & 0.9 & 1.7 \\
Metals & 0.1 & 0.1 & 0.1 & 0.2 & 0.1 & 0.1 \\
Explosives & 0.0 & 0.0 & 0.0 & 0.0 & 0.0 & 0.0 \\
Radioactive isotopes & 0.0 & 0.0 & 0.0 & 0.0 & 0.0 & 0.0 \\
Arms and ammunition & 0.0 & 0.0 & 0.0 & 0.0 & 0.0 & 0.0 \\
Uranium & 0.0 & 0.0 & 0.0 & 0.0 & 0.0 & 0.0 \\
Total & 13.2 & 13.6 & 15.5 & 14.5 & 14.5 & 13.8 \\
\hline
\end{tabular}

Source: Calculated by the author from Japan's customs statistics. 
puters, centrifuges, gas turbine engines, and nuclear reactors. These were followed by machine tools, and optical, measurement, and analysis instruments.

The growth in the intra-industry trade index, which was mainly caused by the increase of machinery imports from China, and the high share of sensitive items in Japan's exports to China reflect the development of international value chains that spread across both countries. With the diffusion of technology, massive foreign direct investment, and the spread of modular production networks (Sturgeon 2002), China has assumed the role of assemblers of electronic machinery and computers in the global value chain. Though China's role may not necessarily include high-value-added activities, the items assembled in China do involve high technology within their components and design. As the industries of both countries are intertwined in the value chain, any strengthening of controls on the export of high-tech items from Japan to China may be harmful for not only Chinese industries but also Japanese industries.

\section{Japan's Export Control Regime and China}

When the People's Republic of China was established in 1949, Japanese business communities and even the government expected that the development of trade with China would help Japan's postwar economic recovery. However, the outbreak of the Korean War in the following year led to a sharp decline in trade, because the Supreme Commander for the Allied Powers that still occupied Japan banned the exports of controlled items to China, Hong Kong, and Macau (Katō 1992, 110-112; Yasuhara 1986). The control on trade with China was relaxed only slightly after the end of occupation as Japan joined COCOM in 1953. After negotiations with the United States, Japan agreed to control exports to China, not as strictly as the United States did but far more strictly than the European countries did (Katō 1992, 163-172).

Japan's commitment to COCOM, however, was mainly motivated by the desire to maintain a good economic relationship with the United States rather than by concerns about its own security (Suzuki et al. 2004). Japan's concentration on economic development, which was made possible by its security treaty with the United States, later developed into an avoidance of arms trade as a whole rather than an attempt to play an active role in strengthening the military power of the Western bloc. In 1967, Japanese prime minister Eisaku Sato elu- 
cidated the "Three Principles on Arms Exports," which prohibit arms exports to Communist countries, to countries that the United Nations resolutions prohibit arms exports to, and to countries that are, or have a possibility to be, involved in international conflicts. In 1976, Prime Minister Takeo Miki, emphasizing Japan's national policy to be a "peace-seeking nation" (heiwa kokka), further strengthened the restrictions, which resulted in a virtual arms embargo. Since then, Japan has refrained from arms exports not only to Communist countries like China but also to its allies, including the United States. The virtual embargo lasted for more than thirty years. The Three Principles were partly relaxed in December 2011, allowing arms exports to the countries with which Japan had security cooperation. The relaxation has been discussed in the context of strengthening strategic ties with allies to contain the military rise of China (Asahi Shimbun, April $28,2012)$. It seems to indicate that Japan has evolved from sheer avoidance of arms trade to an arms trade policy based on its own security concerns.

Though the Three Principles have inhibited Japan from directly exporting arms to China, the country has been exporting dual-use technology in the form of machinery and equipment. Thus, a large portion of Japan's exports to China has been the subject of export control scrutiny. Before 1994, when COCOM still existed, exports of Japanese high-tech machinery to China were often restrained by COCOM regulations. Under the COCOM regime, exports by members could be stopped by opposition from other members, and the United States occasionally vetoed some of Japan's exports to China on the grounds that they involved dual-use technology. Since trade tensions were high between the United States and some of the Japanese exporters at this time, some Japanese media complained that COCOM was being used by the United States to curb the rise of Japanese industries. For example, in 1983, the export of electronic telephone switches by Hitachi to China was suspended for several months because the United States opposed their export on the grounds that the equipment could be put to military use (Nihon Keizai Shimbun, June 16, 24, 1983). In 1985, some Japanese electronics manufacturers, including Panasonic and Hitachi, planned to establish plants in China to manufacture video tape recorders (VTRs). They had to postpone their plans for several years, because the Japanese Ministry of International Trade and Industry (MITI) warned them that VTR production involved dual-use technologies, such as precision machining to make their cylinder heads, and their 
transfer to China would be prohibited by COCOM (Nihon Keizai Shimbun, January 12, 1985). Hitachi received permission from MITI to export the machinery in 1989 on the condition that it was technologically downgraded (Nishii 1990). Panasonic's project was postponed until 1994, when the company finally started operating a joint venture in Dalian to make VTR components. The launch of this venture turned out to be too late, because Chinese consumers' interest in VTRs had already switched to video CD players while Panasonic was in negotiations. Even the testing machinery used in television production lines was the subject of COCOM controls during the 1980s. In 1987, four employees of Toshiba and some trading companies were prosecuted for exporting testing machinery to China without permission (Nihon Keizai Shimbun, March 28, 1987). The transfer of equipment for manufacturing integrated circuits (ICs) was also controlled during the 1980s. Japanese electronics manufacturers were only allowed to export the machinery to produce linear ICs for television sets, because more sophisticated ICs were regarded as dual-use technology.

Faced with these incidents, Japanese media and business leaders came to regard COCOM as an obstacle keeping Japanese businesses from pursuing their commercial interests in China and Eastern Europe, which often led to the loss of business opportunities (Nishii 1990). Such criticisms against COCOM intensified especially after the Toshiba Machinery Incident or the Toshiba-Kongsberg Incident (Wrubel 1989) in 1987, in which a subsidiary of Toshiba exported machine tools illegally to the Soviet Union, which allegedly contributed to the improvement of Soviet submarine screws. As an infuriated US Congress imposed sanctions against Toshiba (which might not necessarily be held responsible for the malfeasance of its subsidiary), many Japanese media and business leaders felt that the United States was using COCOM as a pretext to "bash Japan" and curb the rise of Japanese industries (Chinworth 2004; Katō 1992, 254).

There were, however, some Japanese journalists who pointed out that security issues should hold more weight in the decisionmaking practices of Japanese businesses (Hasegawa 1987). With such arguments by the conservatives, and pressure from the United States, the Japanese Diet amended the Foreign Exchange and Foreign Trade Law in September 1987 to formally incorporate security concerns into trade policy. Since then, the law has required exporters to seek the approval of MITI if the export is "considered to influence the preservation of international peace and security." To help firms to 
comply with export control regulations, the Center for Information on Security Trade Control (CISTEC) was established in 1989, and around two thousand firms prepared compliance programs to strengthen internal controls (Suzuki et al. 2004; Katō 1992, ii).

When the amendment of the Foreign Exchange and Foreign Trade Law was discussed at the Diet, there was a serious conflict between the Ministry of Foreign Affairs (MOFA), which demanded to be more involved in the approval process to reflect security concerns about trade policy, and MITI, which wanted to minimize MOFA's involvement to maintain the principles of free trade. A compromise between the two ministries was reached by including a clause that enabled MITI to "consult MOFA and other related ministries" and MOFA and others to "express its opinion" in implementing export control (Nihon Keizai Shimbun, July 21, 1987; Asahi Shimbun, July 23, 1987; Mainichi Shimbun, July 30, 1987). Export control has remained generally under the sole control of MITI even after the amendment. This explains why economic objectives have often been given more weight than security concerns in Japan's export control.

Ironically, when Japan reinforced its export control regime, the Cold War was about to end and COCOM restrictions started to relax (Satō 2000). In 1988, COCOM decided to relax controls on exports of telephone switches, mainframe computers, semiconductor manufacturing equipment, and some other sophisticated machinery to China (Nihon Keizai Shimbun, September 3, 1988). Following this decision, NEC, a Japanese electronics manufacturer, established two joint ventures with Chinese state-owned enterprises to produce integrated circuits and telephone switches (Nihon Keizai Shimbun, October 7, 1988). The IC joint venture constituted part of China's efforts to localize the production of ICs. The Chinese Ministry of Electronics Industry had been advocating the necessity of creating IC production facilities in China, because of the rising importance of electronics in modern warfare (Hu 2001, 346). After the Gulf War, their appeals were sanctioned by Chinese leaders, and the ministry launched the 908 Project, an IC factory in Wuxi. ${ }^{2}$ Along with creating a domestic manufacturer, the ministry tried to draw NEC into its endeavors to fully develop the IC industry in China. The establishment of the joint venture was a condition NEC had to meet before it could produce and sell telephone switches in China. ${ }^{3}$

NEC was more involved in China's IC localization plans later. The ministry regarded the 908 Project as somewhat of a failure in its 
attempts to catch up with advanced IC manufacturing technology, so it launched the 909 Project in 1997. To extract the latest technology from the entities at the forefront of the IC industry, the ministry solicited capital investment from global IC manufacturers. NEC responded to this call and transferred the technology of manufacturing state-of-the-art dynamic random access memories (DRAMs) to the joint venture.

Although it was clear that China's intention to develop IC manufacturing was to modernize not only its industry but also its weapons, and MITI and MOFA were both nervous about NEC joining the 909 Project, NEC was not prevented from doing so (Nikkei Sangyo Shimbun, October 31, 1997). One reason was that COCOM no longer existed, and the 1996 Wassenaar Arrangement that succeeded COCOM was far less strict and did not target exports and technology transfers to China. Perhaps another reason was that it seemed unlikely that China would catch up with Japan just by establishing one IC joint venture, given the rapid progress of IC manufacturing technology. Indeed, the 909 Project ran into trouble in 2001, the third year of its operation, and its management had to give up the production of DRAMs and transform the venture into an IC foundry by accepting investment from the US company Jazz Semiconductors.

Since the dissolution of COCOM in 1994, Japan's export control regime is based on its Foreign Exchange and Foreign Trade Law. That law and MITI's 1991 Regulation on Export Trade Control, which is based on the Foreign Exchange and Foreign Trade Law, form two layers of restrictions. The first layer is a list of merchandise and technology that can be used in manufacturing various types of weapons. Exports of items on this list to any country require the permission of the Ministry of Economy, Trade, and Industry (METI) ${ }^{4}$ Even if a certain item is not on the list, its export can be restricted if it will be exported to particular firms or if it will be used in making weapons. This is the second layer of restrictions. The firms on the restricted list include military-related enterprises and institutions in Iran, North Korea, China, India, Syria, Pakistan, and a few other countries.

The list of sensitive merchandise and technology, which makes up the first layer of Japan's current export control regime, reflects Japan's commitments to international export control regimes such as the Wassenaar Arrangement, which aims to control the exports of conventional arms and dual-use goods and technologies; the Nuclear Suppliers Group; the Australia Group, which controls the transfer of 
items related to chemical and biological weapons; and the Missile Technology Control Regime. It includes the following items: arms and ammunition; nuclear reactors and fuels; machinery and materials that can be used to make chemical and biological weapons and missiles; advanced materials such as superconductors, bearings, numerically controlled machine tools, measuring instruments, robots, integrated circuits, and the equipment and materials for manufacturing them; computers; telecommunications equipment such as electronic switches and optical fibers; sensors; navigation devices; submarines; gas turbine engines; rockets; unmanned aerial vehicles; and explosives. The list includes many items in which Japan has a strong comparative advantage, and which are widely used by Chinese civilian industries. As shown in Table 1, around 15 percent of Japan's exports to China are of items deemed sensitive.

With the detailed listing of controlled items in Japan's Regulation on Export Trade Control and the reinforcement of its export control regime after the Toshiba Machinery Incident, incidents regarding export controls have decreased. Occasionally, some companies are prosecuted for violating export control laws, but few of them are related to China. One of the rare cases is that of Yamaha Motor Company, which exported unmanned helicopters to China from 2001 to 2005. The helicopters were designed to spray pesticides, but their exports were controlled because they could be used to spray chemical and biological weapons (Nihon Keizai Shimbun, January 23, 2003). In another case, Shin Toyo Machinery exported anticorrosive pumps to a subsidiary of JFE Steel in Guangdong. Exports of anticorrosive pumps require METI's permission because such pumps can be used for making chemical weapons (Nihon Keizai Shimbun, September 13, 2011). As can be seen from these two cases, the items under scrutiny are very specific compared to the generic items that had been barred from export to China during the 1980s.

\section{Technology Leakage Through Trade}

As discussed in the previous section, Japan's export control regime is based on preventing the proliferation of weapons of mass destruction and the accumulation of weapons that leads to international conflicts. As China competes with Japan in more and more industries, however, some Japanese industries are demanding that the government prevent technology leakage to preserve Japan's technological leadership. At present, Japan's export controls only prevent exports and 
technology transfer that directly or indirectly relate to military purposes, but there are some signs that the Japanese government is trying to devise measures to curb exports and technology transfer that may damage Japan's technological supremacy. Three industry cases that have attracted widespread public attention in Japan during the past ten years-die and mold, high-speed rail, and rare earth application technology — are discussed in detail below.

\section{The Die and Mold Industry}

In 2002, the Japan Die and Mold Industry Association (JDMIA) started to lobby ruling-party members of the Diet and METI to take measures to prevent the leakage of Japanese die and mold technology to China. In Japan, dies for stamping and molds for plastic injection are usually produced by independent manufacturers, and the users of these dies and molds are manufacturers of electronic products, cars, and their components. The original design of these products and components is undertaken by the latter, and provided in the form of computer-aided design (CAD) data. The die and mold makers then consider the design from the viewpoint of manufacturing efficiency and reconfigure the CAD data to make the dies and molds. The existence of a large number of independent die and mold makers is a common feature of Japanese and Chinese industries, which differs from US and European industries (Taguchi 2011).

According to the JDMIA, some Japanese users started to demand that Japanese die and mold makers provide their CAD data. The users would then provide the data to Chinese die and mold makers free of charge and let them make identical dies and molds. The Japanese die and mold makers received nothing in exchange. Users were able to procure cheaper dies and molds from Chinese makers that had an advantage in input cost but lacked expertise in designing high-quality dies and molds. Japanese die and mold makers resented such industry practices because they received orders only for the first die and mold for a certain product, while the subsequent orders were placed with less expensive Chinese firms. Since die and mold makers are in a weak position relative to their customers, they cannot refuse to provide the $\mathrm{CAD}$ data or ask for compensation. It is also difficult to argue infringement of intellectual property rights by the users or the Chinese die and mold makers because the CAD data for making the dies and molds are based on the user's original design. It would be hard to make a case that the die and mold maker has sole ownership of the CAD data. In response, the die and mold makers 
lobbied the Japanese government for measures to prevent such practices by users.

Responding to the appeal by JDMIA and pressure from rulingparty politicians, METI issued the "Guideline to Prevent Unexpected Leakage of the Drawings and Processing Data of Dies and Molds" in July 2002, which urged die and mold makers to be more sensitive in protecting their intellectual property rights and urged users not to take advantage of their strong position against die and mold makers. In March 2003, METI issued the "Guideline for Preventing Technology Leakage," which urged Japanese enterprises to learn the best practices among Western companies of preventing technology leakage. These measures, however, have not prevented Japanese users from placing orders with the Chinese die and mold industry or curbed its growth at the expense of Japanese makers. The decline of the Japanese die and mold industry and the catching-up of the Chinese industry continued, especially after 2008 (Development Bank of Japan 2012). In 2013, METI began to draft a new guideline for preventing technology leakage through engineers who had retired or resigned from Japanese enterprises (Nihon Keizai Shimbun, May 30, 2013).

\section{China's High-Speed Railway}

When the Chinese government's plan to build a high-speed railway between Beijing and Shanghai was made public in the 1990s, Japanese business circles and even some ruling-party politicians prodded Chinese leaders to adopt the Japanese Shinkansen (high-speed railway) system (Yomiuri shimbun chūbu shakaibu 2002). After some efforts to develop high-speed rolling stock through its own R\&D resources, the Chinese Ministry of Railways finally decided to introduce technology from Germany, France, and Japan and to localize and improve them at CSR Corporation and CNR Corporation, which are state-owned rolling stock manufacturers governed by the ministry. Japanese rolling stock manufacturers saw China's high-speed railway plan as an opportunity to expand their sales. Kawasaki Heavy Industries (KHI) exported some rolling stock to China identical to the ones that it supplied to the Japan Railway companies, and established a joint venture with CSR Corporation to aid with localization. CSR Corporation reverse-engineered KHI's rolling stock and developed new types that could run faster than the Japanese ones (Shūkan Tōyō Keizai, April 19, 2008; Shükan Ekonomisuto, October 14, 2008). 
Since the start of its operation in China in 2008, the high-speed railway system has grown very rapidly, and the total length of its network far exceeds that of the Japanese Shinkansen network. This rapid development has attracted the attention of some other nations that have plans to build high-speed railway networks. CSR Corporation even applied for patents on rolling stock in the United States in June 2011. The leaders of the Japan Railway system were irritated at the rapid emergence of China as a competitor, alleging that it was the result of unexpected technology leakage (Nihon Keizai Shimbun, July 11, 2011). Somewhat similarly to the case of dies and molds, rolling stock and other equipment in the Japanese high-speed railway system have been jointly developed by the railway operators (Japan Railway companies) and the manufacturer. From the viewpoint of Japan Railway's operators, their technology was transferred to the rolling stock manufacturers such as KHI, and through exports by the latter it was transferred to China against the wishes of the Japan Railway companies. In an interview with the Financial Times (April 6, 2010), Yoshiyuki Kasai, the chairman of Central Japan Railway Company, denounced the Chinese railway system for stealing foreign technology.

The conflict regarding the alleged leakage of Shinkansen technology has mainly been fought between the Central Japan Railway Company and KHI, but the Ministry of Land, Infrastructure, Transport, and Tourism attempted at one point to establish a group to study measures to preserve Japan's technological supremacy in the railway industry. However, the group was not established because of opposition from Japanese firms that supply rolling stock and components to China's railway system (Sankei Shimbun, January 12, 2011).

\section{Rare Earth Application Technology}

China has been imposing restrictions on rare earth exports since 1998, while the country accounted for $94-97$ percent of global production during 2002-2011. The Chinese government explains that the purpose of restricting export of rare earth metals is to prevent the depletion of a limited natural resource and to prevent environmental destruction caused by mining these elements (State Council Information Office 2012). Judging by the discussions inside China, however, another important purpose of the restriction is to promote the development of rare earth application technology in China (Wang 2011). The Chinese government launched an ambitious ten-year development plan for alternative energy vehicles in 2011, which included the 
localization of critical components such as motors and rechargeable batteries that use rare earth metals.

The Japanese government and business community were sufficiently concerned that they demanded that China lift the export restriction. Though rare earths constitute less than 0.1 percent of Japan's imports from China, tensions were high because they are considered to be a crucial input in some important Japanese products, such as hybrid electric vehicles and liquid crystal displays. During the summer of 2010, both the Japanese foreign minister and the head of Keidanren (the Japan Business Federation) went to China and asked Chinese leaders to remove the restriction. Soon after these visits, however, a Chinese fishing boat collided with a Japanese Coast Guard vessel near the Senkaku/Diaoyu Islands. The incident was followed by a warning from the Chinese premier that China would take further action if Japan did not release the captain of the fishing boat at once. A few days after this warning, it was reported that rare earth exports from China to Japan were suspended. Although rare earth exports returned to normal within a few months, the Japanese government realized the risk of heavy dependence on China for rare earth metals.

Together with the United States and the European Union, the Japanese government filed a World Trade Organization dispute settlement case in March 2012 against China over its restrictions on rare earth exports. In August 2012, they also amended the Regulation on Export Trade Control to include "high-performance magnets, and their manufacturing equipment and parts" in the list of items that needed METI's approval for export. METI explained that this amendment was based on the concern that high-performance magnets would be used for the improvement of missile technology (Nihon Keizai Shimbun, July 28, 2012, February 12, 2013, electronic ed.). But perhaps a hidden motivation for this action was to prevent the leakage of rare earth application technology in which Japan had technological leadership. High-performance magnets use two rare earth elements, neodymium and dysprosium, as materials, and China virtually monopolizes the global supply of the latter. As supplies of rare earth metals from China became unstable after 2010, Japanese manufacturers Hitachi Metals, TDK, and Shin-Etsu Chemical, the global leaders in the high-performance magnet industry, planned to establish joint ventures in China to secure their supply of the elements and retain customers that often had Chinese production sites. It was feared that this would help China to acquire rare earth application 
technology and so METI put a stop to the establishment of these joint ventures.

However, the Japanese magnet manufacturers feared that the virtual ban on the magnet venture imposed by the amendment would harm their competitiveness. The chairman of Hitachi Metals lobbied METI to reverse the amendment and let the company establish a production site in China. Japanese magnet makers are losing the competition with their Chinese rivals because of the high cost of the rare earth metals, and manufacturers that use such magnets are replacing Japanese magnets with Chinese ones.

The decline of Japanese magnet makers and the rise of Chinese makers seem likely to accelerate based on the new restrictions. If METI's policy is purely based on the concerns over the proliferation of missile technology, this may not pose a problem. But if there is a hidden motive similar to that of China's export restrictions in the first place, as I suspect, the new policy is creating a result quite contrary to its purpose.

As these three cases illustrate, as Chinese industries catch up with Japanese industries, accusations from Japan over technology leakage are increasing; however, the Japanese government is ill equipped to prevent such leakage. Since Japan's technological supremacy has been the basis for a sound relationship with China, Japan has strong incentives to preserve it for both economic and security reasons. However, it is difficult to implement preventive measures because there is a divergence of interests between different industrial sectors in Japan. Technology leakage in a certain industry may damage the interests of its manufacturers but may benefit other industries. It is also difficult to use current export control regulations effectively, because they only restrict exports that directly or indirectly relate to military purposes. The high-performance magnet case is a rare one in which the Japanese government used the current export control regime to handle technology leakage in a civilian industry, but this action may turn out to be harmful in the long run to the overall interests of Japanese manufacturers.

\section{Conclusion}

The relative positions of Japan and China have changed drastically during the past thirty years. Until the 1990s, Japanese businesses had little concern that high-tech exports and technology transfer to China would threaten national security or endanger Japan's technological 
supremacy. They seemed to regard COCOM restrictions simply as an obstacle to expanding their business in China, a regime that imposed ungrounded restrictions on their transfer of civilian technology. After the dissolution of COCOM, restrictions on the transfer of civilian technology were largely relaxed while restrictions on exports of arms and dual-use technology were strengthened in Japan. Since then, Japanese businesses have rarely been vexed by export control regulations in doing business with China, in part because Japanese businesses had largely withdrawn from arms exports since the declaration of the Three Principles on Arms Exports in 1967.

With the economic and military rise of China and new tensions between Japan and China since 2010, Japan faces a dilemma. Its business interests necessitate the export of high-technology items and the transfer of technology to China. But such actions may help China's rise and harm Japan's national security. Concerns about the effect of Japan's exports and technology transfer on China's military buildup, however, are seldom raised. This is perhaps because the exports of arms and sensitive items are already considered well controlled. It may also be because MOFA and the Ministry of Defense are not involved in Japan's export control regime. As a result, business interests tend to dominate implementation.

Concerns about the erosion of Japan's technological supremacy as a consequence of exports and technology transfer, on the other hand, have been raised by several Japanese industries. With the acceleration of the deterioration of the Japanese public's feelings about China, such concerns are gaining public attention. A public survey conducted by the Japanese Cabinet Office every year reveals that the percentage of those who are antipathetic to China is increasing rapidly. The percentage hovered around 40 to 50 percent between 1989 and 2003, but it increased to more than 60 percent in 2005, when anti-Japanese demonstrations spread across China, and it reached a historic high of 80.6 percent in October 2012, following the escalation of tensions over the Senkaku/ Diaoyu Islands. Under such circumstances, accusations about technology leakage to China will easily gain public attention and may lead to demands on the Japanese government to take more effective measures to prevent them. The present export control regime, however, is not well equipped to respond to such demands for the reasons outlined, and it will be a difficult task for the Japanese government to incorporate effective measures to prevent technology leakage into its trade policy. 
Tomoo Marukawa is professor of Chinese economy at the Institute of Social Science, University of Tokyo. Prior to this position, he was a researcher at the Institute of Developing Economies. His recent books (in Japanese) include Contemporary Chinese Economy (2013), Chinese Dream: Mass Capitalism Changes the World (2013), and Contemporary Chinese Industries (2007). His research areas include China's industrial and technological developments, Sino-Japanese economic relations, and renewable energy industry.

\section{Notes}

1. The intra-industry trade index is defined by

$$
\mathrm{GL}=1-\left(\sum_{i}\left|E_{i}-I_{i}\right|\right) /\left(\sum_{i}\left[E_{i}+I_{i}\right]\right),
$$

where $\mathrm{E}_{i}$ and $\mathrm{I}_{i}$ denote the value of exports and imports of the $i$ th industry. The index varies between 0 and 1 . GL $=1$ means that the value of exports and imports of all industries are exactly the same, while GL $=0$ means that in all industries, there is either only import or only export, that is, no intraindustry trade in any of the industries. Here, an "industry" denotes a onedigit class of the Standard International Trade Classification (SITC).

2. Author interview with Yu Zhitian, former adviser to the minister of information industry, March 9, 1999.

3. Author interview with Noriyuki Yamamoto, Shougang NEC Electronics, March 17, 1999.

4. MITI was reorganized into the Ministry of Economy, Trade, and Industry in 2001.

\section{References}

Chinworth, Michael. 2004. "Tōshiba kikai jiken no saikentō" [The Toshiba machinery incident revisited]. Kokusai anzen hoshō 32, 2: 99-118.

Development Bank of Japan. 2012. "Nihon no monozukuri o sasaeru kanagata sangyō no kadai" [The problems of the die and mold industry which supports Japanese manufacturing]. Kongetsu no topikkusu 179. www.dbj.jp/reportshift/topics (accessed June 1, 2013).

Fukao, Kyoji, Hikari Ishido, and Keiko Ito. 2003. "Vertical Intra-Industry Trade and Foreign Direct Investment in East Asia." Journal of the Japanese and International Economies 17, 4: 468-506.

Hasegawa, Keitarō. 1987. "Koritsuka o maneku 'seiji wa seiji, shōbai wa shōbai' rosen" [The attitude to separate politics and business will lead us to isolation]. Kakushin 206: 10-14.

Hu, Qili. 2001. Zhongguo xinxihua de tansuo yu shijian [The quest and practice for China's information society]. Beijing: Dianzi gongye chubanshe.

Katō, Yōko. 1992. Amerika no sekai senryaku to kokomu: 1945-1992 [US global strategy and COCOM: 1945-1992]. Tokyo: Yushindō kōbunsha.

Kojima, Sueo. 2012a. "Nicchū chōki bōeki torikime no teikeitsu" [The conclusion of the Japan-China long-term trade agreement]. In Nicchu 
kankei shi: 1972-2012 II Keizai [A history of Japan-China relations: 1972-2012 II Economy], ed. K. Hattori and T. Marukawa, 71-78. Tokyo: University of Tokyo Press.

. 2012b. "Puranto keiyaku mondai" [The plant contract issue]. In Nicchü kankei shi: 1972-2012 II Keizai [A history of Japan-China relations: 1972-2012 II Economy], ed. K. Hattori and T. Marukawa, 121-128. Tokyo: University of Tokyo Press.

Nishii, Yasuyuki. 1990. "Kokomu byō' wazurau nihon kabushiki gaisha" [The Japan Inc. suffering from 'COCOM disease']. Asahi Journal 32, 9: 29-31.

Satō, Heigo. 2000. "Kokomu kara wassenā e" [From COCOM to Wassenaar]. Hitotsubashi ronsō 123, 1: 114-130.

Sekiyama, Takashi. 2012. "Taichū ODA no kaishi" [The beginning of ODA to China]. In Nicchū kankei shi: 1972-2012 II Keizai [A history of Japan-China relations: 1972-2012 II Economy], ed. K. Hattori and T. Marukawa, 105-119. Tokyo: University of Tokyo Press.

State Council Information Office, People's Republic of China. 2012. Zhongguo de xitu zhuangkuang yu duice [The status of China's rare earths and policy]. Beijing: Renmin chubanshe.

Sturgeon, Timothy J. 2002. "Modular Production Networks: A New American Model of Industrial Organization." Industrial and Corporate Change 11, 3: 451-496.

Suzuki, Tatsujirō, Masayuki Tadokoro, Hideaki Shiroyama, Setsuko Aoki, and Ryōko Kuzumi. 2004. "Nihon no anzen hoshō bōeki kanri" [Japan's security trade governance]. Kokusai anzen hoshō 32, 2: 1-30.

Taguchi, Naoki. 2011. Sangyō gijutsu kyōsōryoku to kanagata sangyō [Industrial and technological competitiveness and the die and mold industry]. Kyoto: Minerva Shobō.

Wang, Junzhi. 2011. Zhongguo xitu baowei zhan [The war for protecting China's rare earths]. Beijing: Zhongguo jingji chubanshe.

Wrubel, Wende A. 1989. "The Toshiba-Kongsberg Incident: Shortcomings of COCOM, and Recommendations for Increased Effectiveness of Export Controls to the East Bloc." American University International Law Review 4, 1: 241-273.

Yasuhara, Yoko. 1986. "Japan, Communist China, and Export Controls in Asia: 1948-52." Diplomatic History 10, 1: 75-89.

Yomiuri shimbun chūbu shakaibu. 2002. Umi o wataru shinkansen [The export of Shinkansen]. Tokyo: Chūō kōron shinsha. 


\section{We help Asia speak to the world and the world speak to Asia.}
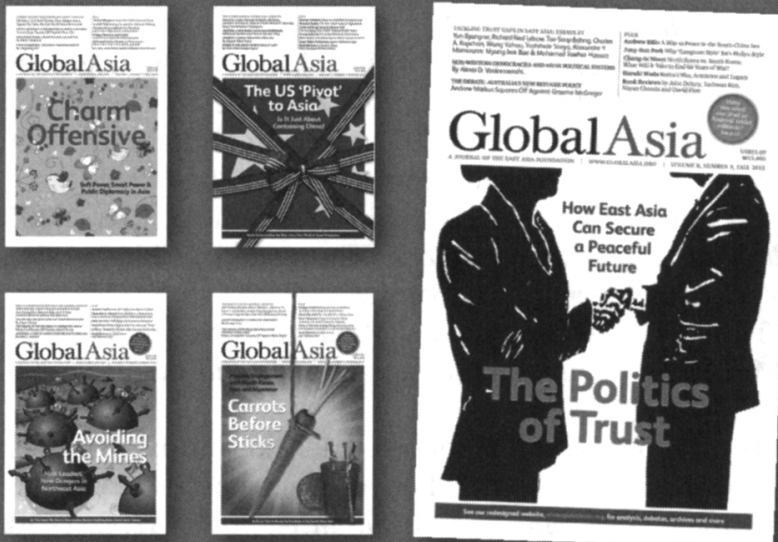

\section{Can you afford not to read Global Asia?}

Find out more today at our freshly redesigned and improved website, www.globalasia.org. Now with a new, expert current affairs blog and comprehensive, easy-to-search archives.

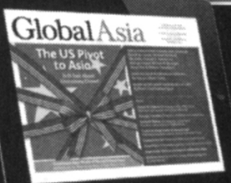

Global Asia is now also available on iPad and Android tablets. Download any issue for just \$5.99 from Apple or Google app stores today. 